\title{
PHOSPHATE ROCK.
}

By R. W. Stone.

Prior to 1914 the United States was producing annually close to $3,000,000$ tons of phosphate rock, of which over 99 per cent came from Florida, Tennessee, and South Carolina. Florida produced more than 75 per cent of the total output, including the great bulk of the material exported, which was orer 40 per cent of the total. With the beginning of the war the facilities for shipping phosphate rock to Europe were greatly decreased. Many Florida plants were shut down, and they have not resumed operations.

The proportion of exports to total production dropped from about 42 per cent in 1912 and 1913 to 35 per cent in 1914 and less than 14 per cent in 1915. In 1915 the total production was only 60 per cent of that in 1913. In 1916 the industry was in some areas practically demoralized, but there was nevertheless a gain over 1915. The total output in 1916 was $1,980,000$ tons, valued at $\$ 5,897,000$.

Percentage of phosphate rocli produccl, by States, 1912-1916.

\begin{tabular}{|c|c|c|c|c|c|}
\hline state. & 1912 & 1913 & 1314 & 1015 & 1.916 \\
\hline $\begin{array}{l}\text { Florida......... } \\
\text { Tennessee....... } \\
\text { South Carolina... } \\
\text { Other States.... }\end{array}$ & $\begin{array}{r}81.0 \\
14.2 \\
4.4 \\
.4\end{array}$ & $\begin{array}{r}\$ 2.0 \\
1.4 .5 \\
3.5 \\
.2\end{array}$ & $\begin{array}{r}78.0 \\
118.0 \\
3.9 \\
.1\end{array}$ & $\begin{array}{r}i 4.0 \\
21.0 \\
4.5 \\
.5\end{array}$ & $\begin{array}{r}70.0 \\
21.0 \\
2.7 \\
.3\end{array}$ \\
\hline & 100.0 & 100.0 & 100.0 & 100.0 & 100.0 \\
\hline
\end{tabular}

As shown by the table, Tennessee, in spite of decreased production, has produced a larger proportion of the country's output since the war began than in time of peace. It would seem as if the Tennessee industry, which has not been bound up so much in the export trade and which is equipped in part with modern machinery for mining by modern methods, should develop while the European trade is restricted and while the industry in Florida and South Carolina is more or less dormant.

The deposits of phosphate rock in the United States are confined very definitely to the southeastern part of the country and to the 
Rocky Mountain region from the latitude of Salt Lake City, Utah, to that of Helena, Mont. Although by far the largest deposits are in the Western States, the production from that region is less than 1 per cent of the whole, owing to the lack of a large market in the region at present and to high freight rates on the crude rock. The western rock-phosphate deposits are so extensive that, even if the entire world depended on them for its supply of phosphate, they. would not be exhausted in many generations.

The Florida phosphate deposits comprise three classes of phosphate-hard rock, land pebble, and river pebble. The hard rock is the highest grade, the land pebble is produced in the largest quantity, and the river pebble is not mined at present. The area of hardrock deposits forms a narrow strip along the western part of the Florida Peninsula from Suwannee County to Pasco County, a distance of approximately 100 miles. The land-pebble phosphate area lies just east of Tampa and is about 30 miles long from north to south and 10 miles wide. The sales of Florida phosphate have decreased greatly since 1913 . In that year $2,500,000$ tons was sold for $\$ 9,500,000$; in 1915 the production was $1,350,000$ tons, valued at $\$ 3,700,000$. In 1916 the industry began to recover, and the output was over $1,500,000$ tons, valued at $\$ 4,170,000$.

The South Carolina output consists of land-rock phosphate mined in the vicinity of Charleston. River-pebble phosphate occurs in the same area but is not mined. Some of the South Carolina output has been exported annually. The sales have decreased from 169,000 tons in 1911 to 53,000 tons in 1916 , and the value from $\$ 673,000$ to $\$ 211,000$.

The Tennessee deposits of rock phosphate are in the west-central part and extreme northeast corner of the State. The latter have not been mined. Three types are recognized and known by their colors as brown, blue, and white rock. The white rock has not been mined recently. The brown rock comes from Maury, Giles, Hickman, Lewis, and Sumner counties and is sold under a guaranty of 70 to 80 per cent tricalcium phosphate. The blue rock is mined in Lewis and Maury counties and varies considerably in its phosphatic content. The sales of Tennessee phosphate dropped from 483,000 tons, valued at $\$ 1,823,000$, in 1914 to 390,000 tons, valued at $\$ 1,328,000$, in 1915. In 1916 there was a partial recovery, the output being nearly 412,000 tons, valued at $\$ 1,510,000$.

The phosphate deposits of Kentucky lie between Frankfort and Lexington, and considerable quantities of rock have been mined near Wallace, but the State has been an insignificant producer of phosphate rock in recent years.

Phosphate deposits occur more or less interruptedly for a distance of 80 miles in the north-central part of Arkansas, and a small quantity is produced at Anderson, Independence County. 
Four of the Western States possess vast deposits of high-grade rock phosphate, but the western production amounts to only 3,000 to 5,000 tons a year. In 1916 it was only 1,700 tons. Idaho, Utahi and Wyoming are the producers. Montana is not yet a producer, although at Elliston, Garrison, Philipsburg, and Melrose there are very extensive deposits easy of access and close to rail transportation. The small local demand for fertilizer and lack of cheap transportation will for some years retard the development of these western deposits.

In the southeastern part of Idaho an extensive supply of highigrade phosphate occurs along both sides of Blackfoot River, in Fort Hall Indian Reservation, near Montpelier, and north of Bear Lake. A small quantity is mined in Bear Lake County.

The Utah deposits are east of Great Salt Lake, in the Wasatch and Uinta ranges, and east of Bear Lake. These deposits are extensive, but the material is leaner than the general run of Idaho phosphate, averaging nearer 60 per cent than 80 per cent tricalcium phosphate.

Western Wyoming also is rich in rock phosphate. The deposits are mostly in the Owl Creek, Wind River, Gros Ventre, and Salt River ranges. Some of them are thick beds carrying 80 per cent tricalcium phosphate and extending for many miles, and they constitute a reserve supply that is almost inexhaustible.

An estimate of the quantity of rock phosphate available in the United States was made in 1915 by the United States Geological Survey and need not be revised to account for that mined in the meantime. It is repeated here.

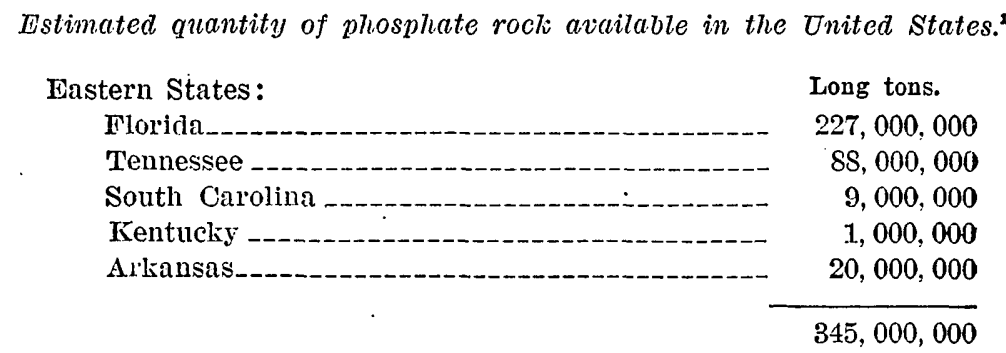

Western States (Montana, Idaho, Utah, and Wyoming)

$5,367,000,000$

$5,712,000,000$

Although the total reserves as shown by this estimate are very. large, the supply of high-grade rock is much less and should not be considered inexhaustible. Lands remaining in Government owner-

1 Phalen, W. C., Phosphate rock in 1915: U. S. Geol. Survey Mineral Resources, 1915, pt. 2, p. 238, 1916. 
ship that are known or believed to contain valuable phosphate deposits have been temporarily withdrawn from entry. The outstanding withdrawals are about 2,500,000 acres in the Western States and 120,000 acres in Florida. The work of surveying the western phosphate lands is still going on.

Any statement as to probable developments in the phosphate industry when peace is declared is largely conjecture. So long as the war continues phosphate rock can not be sent to the large consumer, Germany, and high ocean freight rates greatly restrict and practically stop shipments to other European countries. Furthermore, the demand for sulphuric acid for use in making munitions has raised the prices of acid so high that manufacturers of acid phosphate have been obliged to curtail production. This has reduced the quantity of rock phosphate used by manufacturers of fertilizers and increased the quantity of rock ground for direct application to the soil. It seems reasonable to believe that at the end of the war European nations will want increased quantities of phosphate, for their stores of foodstuffs will be low and intensive cultivation of the soil will be necessary. The demand will again fall largely on the Florida and South Carolina deposits, which are close to the seacoast, and the phosphate industry in those States may then look for marked improvement. 